\title{
THE INFLUENCE OF LIPID-LOWERING THERAPY ON THE ATHEROSCLEROTIC PROCESS IN PATIENTS WITH THE SECOND DEGREE OF ESSENTIAL HYPERTENSION COMBINED WITH ISCHEMIC HEART DISEASE
}

\section{N.M. Serediuk, M.V. Fedorchenko, N.M. Haliuk}

\begin{abstract}
For the purpose of studying the effect of lipid-reducing therapy on the course of the atherosclerotic process in the coronary arteries the authors have examined 30 people, undergoing a course of treatment at the Ivano-Frankivsk Regional Clinical Cardiological Dispensary (RCCD). The patients were randomized into three subgroups based on an evaluation of a risk of cardiovascular events according to the coronary calcium index, a control group of 10 persons was also formed. The concentration of total cholesterol (TCS), triglycerides (TG), cholesterol of lipoproteins of high and low density (CS LPHD and CS LPLD) as well as the index of coronary calcium were evaluated. All the patients were prescribed rosuvastatin in a single dose of $20 \mathrm{mg}$ every evening during four weeks. Upon completing a full course of therapy by all the patients the experiment was repeated. It was established hereat that against a background of a decrease of the levels of TCS, TG, CS LPLD, an increase of the level of the nonatherogenic fraction of CS LPHD an elevation of the index of coronary calcium was observed.
\end{abstract}

Key words: coronary calcium index, lipid-lowering therapy, statins, evaluating risk of cardiovascular events.

National Medical University (Ivano-Frankivsk)

Рецензент - проф. О.І. Федів

Buk. Med. Herald. - 2013. - Vol. 17, № 2 (66). - P.125-129

Надійшла до редакції 08.04.2013 року

(C) Н.М. Середюк, М.В. Федорченко, Н.М. Галюк, 2013

УДК 616.12-009.72-08-06:616.24-002.2-092

В.К. Ташук, Т.М. Амеліна, О.С. Полянська

\section{ОКРЕМІ АСПЕКТИ ЛІКУВАННЯ СТАБІЛЬНОЇ СТЕНОКАРДІЇ ІЗ СУПУТНІМ ХРОНІЧНИМ ОБСТРУКТИВНИМ ЗАХВОРЮВАННЯМ ЛЕГЕНЬ, РЕЄСТРОВІ ДОСЛІДЖЕННЯ}

Буковинський державний медичний університет, м. Чернівці

Резюме. Досліджено вплив $\beta$-адреноблокатора карведилолу на функціональний стан ендотелію у хворих на стабільну стенокардію напруження із супутнім хронічним обструктивним захворюванням легень. Вста-

Вступ. Ішемічна хвороба серця (IXC) залишається найбільш поширеною патологією серця в Україні і становить 67,5 \% серед усіх причин смерті від хвороб системи кровообігу. Незважаючи на видатні успіхи в лікуванні стабільної стенокардії за останні 20 років, включаючи превентивну терапію, фармакологічні засоби і реваскуляризацію, іiі симптоми зберігаються у більшості хворих, які знаходяться в групі високого і дуже високого ризику виникнення ускладнень. Припускають, що серцево-судинні захворювання залишаться провідною причиною смерті і захворюваності населення до 2020 р., у зв'язку з цим лікування IXC посідає одне 3 провідних місць серед найважливіших медичних проблем XXI століття [3].

Хронічне обструктивне захворювання легень (ХОЗЛ) - одна 3 найбільш важливих медикосоціальних проблем як в Україні, так і у світі. Її актуальність зумовлена високими показниками поширеності, інвалідизації, смертності та постійно зростаючими економічними збитками. Дані щодо захворюваності та поширеності ХОЗЛ не(c) В.К. Тащук, Т.М. Амеліна, О.С. Полянська, 2013 новлено, що призначення препарату нормалізує прояви ендотеліальної дисфункції.

Ключові слова: стабільна стенокардія, хронічне обструктивне захворювання легень, карведилол.

дооцінюються, тому що захворювання зазвичай діагностується після появи клінічно значущих симптомів, хоча відомо, що корені ХОЗЛ закладаються на десятки років раніше, ніж з'являються його ознаки. Тяжкість ХОЗЛ у окремого пацієнта зумовлена загостреннями та супутніми захворюваннями За результатами дослідження Global Burden of Disease, що проводилося під патронатом ВООЗ і світового банку, ХОЗЛ посідає четверте місце серед причин смерті у світі з 2,75 млн випадків смерті на рік (1,41 млн - серед чоловіків та 1,34 млн - серед жінок), що становить 4,8 \% від усіх смертей [5]. Смертність від ХОЗЛ стрімко зростає. За даними Європейського респіраторного товариства (ERS), прогнозується зростання смертності від ХОЗЛ до 2020 року, коли вона вийде на 4-те місце після таких захворювань, як IXC, цереброваскулярні захворювання, рак легень, - така тенденція характерна як для Східної, так і для Західної Європи $[1,2]$.

Лікування хворого на IXC, що має супутнє ХОЗЛ, становить одну з актуальних проблем су- 
часної медицини, адже вибір тактики лікування, окрім високої ефективності, повинен бути безпечним, не впливати негативно на функцію зовнішнього дихання, легеневу гемодинаміку та мукоциліарний кліренс.

Мета дослідження. Оцінити вплив $\beta$ адреноблокатора карведилолу на перебіг стабільної стенокардії напруження із супутнім хронічним обструктивним захворюванням легень за станом ендотеліальної дисфункції.

Матеріал і методи. Для реалізації поставленої мети за допомогою сучасних біохімічних та інструментальних методів дослідження обстежено 113 хворих на IXC: стабільну стенокардію (CC) напруження II-III ФК. Середній вік пацієнтів становив $(56,1 \pm 0,76)$ років. Чоловіків було 105 , жінок -8 . Тривалість захворювання 3 моменту встановлення діагнозу становила від одного до шести років. Включення пацієнтів із ХОЗЛ до груп, що аналізувалися, проведено скринінговим методом серед осіб, які надійшли до стаціонару й були відібрані випадковим способом відповідно до надходження. Для вивчення ефективності запропонованого лікування всі обстежені були розподілені на чотири групи: 1-ша група складалася з 30 пацієнтів, хворих на СС без супутньої патології з боку органів дихання, яким проводилась основна терапія (антитромбоцитарна, ліпідзнижувальна) та метопрололу сукцинат; 2-га - 33 хворих на СС без ХОЗЛ, у комплексне лікування яких на тлі основної терапії було включено карведилол замість метопрололу; 3-тя - 20 хворих на СС у поєднанні з ХОЗЛ, котрі отримували основну терапію та метопролол; 4-та група - 30 хворих на СС із супутнім ХОЗЛ, яким на тлі основної терапії замість метопрололу було включено карведилол у дозі 12,5 мг на добу. В обстежених пацієнтів діагностовано ХОЗЛ I-II стадії, яке на момент обстеження відповідало повній ремісії.

Критерії включення пацієнтів у дослідження: наявність у пацієнта верифікованої на підставі скарг, даних анамнезу захворювання, клінічної картини, інструментальних і лабораторних методів дослідження СС напруження II-III ФК і згода на участь у дослідженні. Критерії виключення 3 дослідження: хронічна серцева недостатність IIIIV функціонального класу (NYHA), наявність в анамнезі перенесеного мозкового інсульту, клінічно значущі порушення ритму та провідності серця, хронічна хвороба нирок, цукровий діабет, системні захворювання сполучної тканини та інша соматична патологія, яка супроводжується зміною досліджуваних параметрів і здатна, таким чином, вплинути на результати дослідження.

Вміст ендотеліну-1 (ЕT-1) у плазмі крові визначали за допомогою імуноферментного аналізу 3 використанням наборів реагентів «Віоmedica» (Австрія). Стан пероксидного окиснення ліпідів визначали за вмістом у крові малонового альдегіду (МА) за методикою Ю. А. Владимирова, А.І. Арчакова. Стан окиснювальної модифікації білків (ОМБ) оцінювали за методикою О.Ю.Дубиніної в модифікації І.Ф. Мещишена.
Математична обробка отриманих даних проводилася з використанням варіаційного статистичного аналізу на IBM PC Pentium IV. Достовірність змін варіацій у динаміці лікування у разі нормального розподілу у вибірках визначали за парним критерієм Стьюдента, в інших випадках за непараметричним парним Т-критерієм Уілкоксона, взаємозв'язок між ознаками визначали із використанням кореляційних тестів Пірсона.

Кожен пацієнт дав письмову згоду на проведення дослідження 3 дотриманням основних положень GCP (1996р.), Конвенції Ради Свропи про права людини та біомедицину (1997р.), Гельсінської декларації Всесвітньої медичної асоціації про етичні принципи проведення наукових медичних досліджень за участю людини (1964 2000 pp.) і наказу МО3 України № 281 від $01.11 .2000 \mathrm{p}$.

Результати дослідження та їх обговорення. Нами встановлено, що рівень ЕТ-1 у динаміці лікування зменшився у всіх групах хворих. Однак слід зазначити, що в групах пацієнтів, які перебували на основній терапії з включенням метопрололу, рівень ЕТ-1 не зазнав вірогідних змін: у 1-й групі його рівень зменшився на 5,0 \% і складав 0,38 $\pm 0,02$ фмоль/мл, у 3-й - на 11,6 \% і становив $0,38 \pm 0,04$ фмоль/мл.

Призначення карведилолу призвело до виникнення достовірних змін рівня ЕТ-1 зі зменшенням проявів дисфункції ендотелію. У групі пацієнтів на СC, що приймали карведилол впродовж 14 днів, показник ЕТ-1 знизився на 22,7 \% $(\mathrm{p}<0,002)$ і досяг $0,33 \pm 0,01$ фмоль/мл, у групі пацієнтів із поєднаною патологією його рівень зменшився на 13,2\% $(\mathrm{p}<0,002)$ і становив $0,33 \pm 0,03$ фмоль/мл.

Оксидантний стрес $\epsilon$ істотним чинником розвитку атеросклерозу, ішемії та інфаркту міокарда, хронічної серцевої недостатності, порушень серцевого ритму, у тому числі реперфузійних аритмій [6]. Накопичуючись в надлишку в біологічних середовищах організму, вільні радикали викликають окиснення ліпопротеїнів низької щільності, суттєво збільшуючи їх атерогенний потенціал, а окиснення ліпідного шару клітинних мембран призводить до їх пошкодження та загибелі. Відомо [7], що карведилол зменшує утворення вільних радикалів в нейтрофілах, гальмує окиснення ліпопротеїнів низької щільності, захищає ендотеліальні клітини від ушкодження в умовах оксидантного стресу. За вираженості даного ефекту карведилол перевершує інші $\beta$ адреноблокатори, а також антагоністи кальцію та інгібітори ангіотензинперетворювального ферменту.

За даними кореляційного аналізу із використанням тестів Пірсона, який встановив виражений позитивний кореляційний зв'язок між рівнем ЕТ-1 та ОМБ ( $\mathrm{r}=0,81, \mathrm{p}<0,05)$, рівнем ЕТ-1 і МА у Хворих на IXC у поєднанні з ХОЗЛ у динаміці лікування карведилолом. Це підтверджує, що потужні антиоксидантні властивості цього препарату позитивно впливають на стан судинної стін- 
ки за рахунок зменшення кількості вільних радикалів, нормалізації окисно-відновних процесів. Унікальну антиоксидантну здатність карведилолу пов'язують 3 особливостями хімічної структури препарату: наявністю в його молекулі карбазольної групи, яка зв'язує вільні радикали і створює ефект «пастки». Описаний ефект властивий не тільки карведилолу, але і кільком його метаболітам i, що важливо, не супроводжується виснаженням у клітці пулу природних антиоксидантів - $\alpha$-токоферолу i глутатіону. Завдяки ефекту «уловлювання» вільних радикалів карведилол виявляє значно більш виражену, ніж інші $\beta$ адреноблокатори, захисну дію на органи-мішені при всіх клінічних ситуаціях, що супроводжується доведеним позитивним результатом $[4,6]$.

Позитивний вплив карведилолу на рівень пептиду можна обгрунтувати кількома механізмами. Стимулювальний ефект адреналіну на утворення ЕТ-1 здійснюється через $\mathrm{a}_{1}$ адренорецептори, карведилол володіє властивістю блокатора $\mathrm{a}_{1}$-адренорецепторів, відповідно, він спроможний знижувати рівень ЕT-1, інактивуючи дію адреналіну. Потужні антиоксидантні властивості цього препарату також чинять позитивний вплив на судинну стінку за рахунок зменшення кількості вільних радикалів, що призводить до зниження синтезу вазоконстрикторних речовин.

\section{Висновок}

Призначення $\beta$-адреноблокатора карведилолу позитивно впливає на перебіг стабільної стенокардії із супутнім хронічним обструктивним захворюванням легень шляхом зменшення проявів ендотеліальної дисфункції за рахунок вірогідного зниження рівня ендотеліну-1.
Перспективи подальших досліджень. Встановлення позитивного впливу карведилолу на перебіг стабільної стенокардії із супутнім хронічним обструктивним захворюванням легень дозволить покращити прогноз та якість життя даної категорії пацієнтів.

\section{Література}

1. Іщук С.Г. Діагностика порушень газообміну у хворих на хронічне обструктивне захворювання легень / С.Г. Іщук // Астма та алергія. - 2012. - № 2. - С. 42-56.

2. Распутіна Л.В. Маркери системного запалення та ендотеліальної дисфункції у хворих з поєднаним перебігом хронічного обструктивного захворювання легень та гіпертонічної хвороби / Л.В. Распутіна // Астма та алергія. - 2012. - № 2. - С. 17-21.

3. Шумаков В.А. Изучение течения постинфарктного периода при наблюдении в течение 2 лет, оценка проводимого лечения и приверженности к нему / В.А. Шумаков, И.Э. Малиновская, Л.П. Терешкевич // Укр. кардіол. ж. - 2012. - № 6. - Режим доступу до журн.: http://www.ukrcardio.org/journal.php/article/773.

4. Association of chronic lung disease with treatments and outcomes patients with acute myocardial infarction / J.R. Enriquez, J.A. Lemos, S.V. Parikh [et al.] // Am. Heart J. - 2013. - Vol. 165, № 1. - P. 43-49.

5. Impact of obstructive sleep apnoea on diastolic function / R. Wachter, L. Luthje, D. Klemmstein [et al.] // Eur. Respir. J. - 2013. - Vol. 41, № 2. - P. 376-383.

6. Impact of $\beta_{1}$ - and $\beta_{2}$-adrenergic receptor gene single nucleotide polymorphisms on heart rate response to metoprolol prior to coronary computed tomographic angiography / V. Cotarlan, A. Brofferio, G. Gerhard [et al.] // Am. J. Cardiol. - 2013. - Vol. 111, № 5. P. 661-666.

7. Impact of beta blockade therapy on long-term mortality after ST-segment elevation acute myocardial infarction in the percutaneous coronary intervention era / Y. Sakata, S. Suna, M. Usami [et al.] // Am. J. Cardiol. - 2013. Vol. 111, № 4. - P. 457-464.

\section{ОТДЕЛЬНЫЕ АСПЕКТЫ ЛЕЧЕНИЯ СТАБИЛЬНОЙ СТЕНОКАРДИИ С СОПУТСВУЮЩЕЙ ХРОНИЧЕСКОЙ ОБСТРУКТИВНОЙ БОЛЕЗНЬ ЛЕГКИХ, РЕГИСТРОВЫЕ ИССЛЕДОВАНИЯ}

\section{В.К. Тащук, Т.М. Амелина, О.С. Полянская}

Резюме. Исследовано влияние $\beta$-адреноблокатора карведилола на функциональное состояние эндотелия у больных стабильной стенокардией с сопутствующей хронической обструктивной болезнью легких. Установлено, что назначение препарата нормализует проявления эндотелиальной дисфункции.

Ключевые слова: стабильная стенокардия, хроническая обструктивная болезнь легких, карведилол.

\section{SEPARATE ASPECTS OF TREATING STABLE ANGINA PECTORIS CONCOMITANT WITH CHRONIC OBSTRUCTIVE PULMONARY DISEASE: REGISTERED STUDIES}

\section{V.K. Tashchuk, T.M. Amelina, O.S. Polianska}

Abstract. The influence of the b-adrenoblocker of corvedilol on the functional condition of the endothelium in patients with stable angina pectoris combined with chronic obstructive pulmonary disease has been studied. It has been found out that the prescription of the drug normalizes the manifestations of the endothelial dysfunction.

Key words: stable angina pectoris, chronic obstructive pulmonary disease, corvedilol.

Bukovinian State Medical University (Chernivtsi)

Рецензент - проф. Л.П. Сидорчук
Buk. Med. Herald. - 2013. - Vol. 17, № 2 (66). - P. 129-131 